\title{
Obituary
}

\section{Michael James Tyler, AO (1937-2020): Specialist on the Frogs of Australia and New Guinea}

The international herpetological community suffered a great loss on March 26, 2020, when Michael Tyler, the well-known authority on the frogs of Australia and New Guinea, died in Adelaide, South Australia. He had been admitted to St. Andrew's Hospital on March 23 to be assessed for a chest infection when he suffered a heart attack, then lapsed into a coma and died four days later without regaining consciousness, six hours short of his 83rd birthday. Tyler's path to science was complicated and early on was not strewn with many flowers. One can only admire the persistence with which he was able to achieve his desired goal, despite the many obstacles that arose in his path.

Michael James Tyler was born March 27, 1937 in Surbiton, Surrey, just south of London and the River Thames. His father was an accountant at a large shopping center; his mother had died when he was seven years old. At the age of 12, Tyler was fortunate to win a scholarship to an excellent grammar school which gave him a good foundation in science. As a child he enjoyed keeping tadpoles and watching them slowly turn into frogs. His school enabled him to visit France, Belgium, and Germany (1953), and later, he traveled privately to the Netherlands, Germany, Denmark, and Sweden (1956).

Tyler first decided to become an entomologist and after leaving school he worked part-time for the UK Department of Agriculture where he was an inspector for insect pests that sometimes infested shipments of grain that were being unloaded at the London dockyards. He had also started to work towards a BSc degree part-time at the University of London but developed a tumor on his wrist for which he needed surgery. Because chemotherapy was required over an extended period, he had to withdraw from the university and never completed the degree in England or anywhere else.

As Tyler recovered from his tumor surgery, he volunteered at the British Museum (Natural History) where he met Dr. Malcolm Smith (1875-1958), an honorary associate of the museum who had been the physician to the royal court in Bangkok. Smith was famous as an amateur herpetologist with a deep interest in the herpetofauna of South and Southeast Asia. He told young Tyler that because the tumor might return at any time, he should do whatever he wanted to do for the next five years. Smith himself had cancer at that time and was sad that he had no hope of going to Australia and New Guinea where he knew there were many frogs to be discovered and named, so he encouraged Tyler to go there instead. Tyler then spent more time with Smith to learn as much as possible about amphibians. His first two papers (1958, 1959), on the diet of English Rana esculenta, were prepared under Dr. Smith's guidance.

From conversations with Dr. Smith, Tyler decided definitively to go to Australia and New Guinea. Thus inspired and trained, Tyler decided to go, but lacked sufficient funds to do so. He resorted to a most difficult way to travel such a long distance: hitchhiking on land throughout the enormous Eurasian landmass. Such a protracted journey took him nearly 18 months (!) during 1958 and 1959. As he travelled, 
he worked when he needed money for food. He managed to cross continental Europe from France via Austria and Yugoslavia to Bulgaria, but in Turkey he ended up in a hospital. He had to have his appendix removed in Istanbul and remained there for a few weeks to recover. Then Tyler journeyed to Iran and, crossing the countries of South (Afghanistan, Pakistan, India) and Southeast (Burma, Thailand, Malaysia) Asia, he reached Singapore by 1959 . He then worked below deck as a hired hand on a ship which took several weeks travelling through the Pacific and calling at many places including the island of Java before reaching the port city of Fremantle in the state of Western Australia. His daily diet aboard ship was a rice dish.

Finally arriving in Australia, Tyler had no money, no contacts, and no job. Dreaming of New Guinea, he asked about work that would allow him to travel there. Over time, he offered to work on the almost treeless, arid or semi-arid Nullarbor Plain that stretches between Western and South Australia, as a railway "ganger." His job was to work with another man straightening the railway lines every day after the iconic Indian Pacific train had passed through. The heat was intense by day so they worked in the evenings to prepare the line for the next train the following morning. After a few months of this work, Tyler was injured by a railway "sleeper," as they are called in Australia, one of those heavy concrete ties that hold the two rails together, which had fallen off a truck and badly broken his leg in two places. He was taken by train to South Australia and admitted to the Royal Adelaide Hospital where he had to have surgery to repair his leg. While he was in hospital for six weeks he met some medical students who, most fortuitously, told him that the local medical school was looking to hire a laboratory technician.

The University of Adelaide then employed Tyler until he had saved enough money to travel to New Guinea. There he was offered a position as the manager of a Bird of Paradise farm for nearly one year. He went out searching for frogs with New Guinea Highland natives every weekend and for a couple of weeks of "holiday" when he had a break from the farm. He brought back to Australia many new frogs that he could not identify at the time and was fortunate that this occurred before New Guinea became independent and blocked the removal of any animals from the country.

In 1960, his next (third) paper featured Australian topics (on the lifestyle of Australian lizards), and the following year a note on herpetological data received from the natives in Papua was also published. So the dream of the young naturalist from England came true and the exciting new life of an Australian zoologist began! When he returned to Australia from New Guinea, the University of Adelaide offered him the permanent position of laboratory manager in the medical school and, later, he became concurrently Honorary (that is, unsalaried) $\mathrm{Cu}$ rator of Herpetology at the South Australian Museum. At the end of 1960, Tyler briefly returned to London to make an offer to his school friend, Ella, whom he had known since he was five years old. They married in Australia and lived together happily in Adelaide for almost 60 years. Ella originally worked as a nurse, but after the arrival of their third child, she devoted herself to her husband and family.

Michael Tyler's formal scientific career began as a laboratory assistant (1961-1971), and later, laboratory manager, Department of $\mathrm{Hu}-$ man Physiology and Pharmacology, University of Adelaide (1971-1974). After receiving his M.Sc. degree (1974), he moved to the Department of Zoology as a lecturer (1975-1978) and senior lecturer (1979-1983), and, later, became an associate professor (1984-2001) and visiting research fellow in the Department of Environmental Biology of the same university. The University of Adelaide awarded him the degree D.Sc. in 2002 on the basis of a collection of his published work. Such degrees are rarely awarded in Australia and then only for exceptional work. Beginning in 1962, Tyler had a long and successful association with the South 
Australian Museum (Adelaide), and even became the Chair of the South Australian Museum Board which oversees the museum's management (1982-1992).

Tyler, often called Australia's "Frog Man," was a prolific author and published more than 400 titles. This list includes a dozen books, many of which have been reprinted several times. The frogs and toads of Australia, New Guinea, and some adjacent islands became his main and favorite objects of interest. Among currently recognized taxa, he described 73 new species (including a gastric brooding frog Rheobatrachus vitellinus Mahony, Tyler \& Davies, 1984) and two genera of frogs (Assa and Arenophryne, both myobatrachids). His interests in biology were very broad: taxonomy, natural history, zoogeography, morphology, paleontology, biochemistry, and the history of science and even of medicine! A large number of Tyler's works are devoted to the study of the biochemistry of amphibian skin secretions and their possible applications for pharmacological uses. He paid special attention to the protection of amphibians, which he considered useful bioindicators of environmental change caused by unbridled human activity. The focus of the latter research was the effect of radiation (in the area of uranium mines), various kinds of toxic chemicals used in agriculture, and the introduction of alien species, among others.

In addition to his monograph Papuan hylid frogs of the genus Hyla (1968), Tyler's numerous books include Frogs of South Australia (1966, 1977, revised 1994, 1999 with L.A. Smith \& R.E. Johnstone), Frogs (1976, 1982, 1997), Amphibians of South Australia (1978), Frogs of Western Australia (1984, with L.A. Smith \& R.E. Johnstone), There's a frog in my stomach (1984), Frogs of the Northern Territory (1986, with M. Davies), An introduction to frogs (1987, twice 1989), Australian frogs (1989, 1994, 1997, 1999), Frogs (Encyclopedia of Australian Animals, 1992, 1995), A field guide to Australian frogs (1995, 1999, with J. Barker \& G. Grigg), Frogs as Pets (1996), It's true. Frogs are cannibals (2004, 2006). In 1992, two non-herpetological books were published (Earthworms, and Natural History Museums. Behind the scenes).

Michael Tyler earned many distinctions and honors. He was awarded the Sir Joseph Verco Medal, Royal Society of South Australia (1980), Australian Natural History Medallion (1980), Fellow, Australian Institute of Biology (1988), City of Adelaide, Australia Day Citizen of the Year (1993), Michael Daley Eureka Prize for Science Communication (1997), Fellow, American Association for the Advancement of Science (1998), Riversleigh Medal (1998), for his contributions to knowledge of Australian prehistory, Honorary Fellow, Australian Society of Herpetologists (2002), and Knight of the Sovereign Order of St. John of Jerusalem (2002), for his contributions to zoology and to the community. In 1995, he became an Officer of the Order of Australia (the "AO" after his name), which was introduced by H.M. Queen Elizabeth II in 1975 to recognize the leading citizens of his country (before that, Australians received British insignia). This order was awarded to him for "for service to zoology, particularly through the research and conservation of Australian amphibians." In 2005 his research (in co-authorship) on the odors of various frogs was awarded the Ig Nobel Prize for Biology, a satiric tongue-in-cheek award honoring unusual research.

He served as editor of the Transactions of the Royal Society of South Australia (Adelaide, 1976-1982) and was the editor-in-chief of Applied Herpetology (Leiden-Boston, 20042009).

Tyler's undoubted scientific achievements in the study and conservation of amphibians have been widely recognized both in Australia and abroad. As an early indication of his growing international reputation, he was invited by the Museum of Natural History at the University of Kansas, one of the leading programs for herpetological research and graduate education in the USA, to spend a month in 1970 


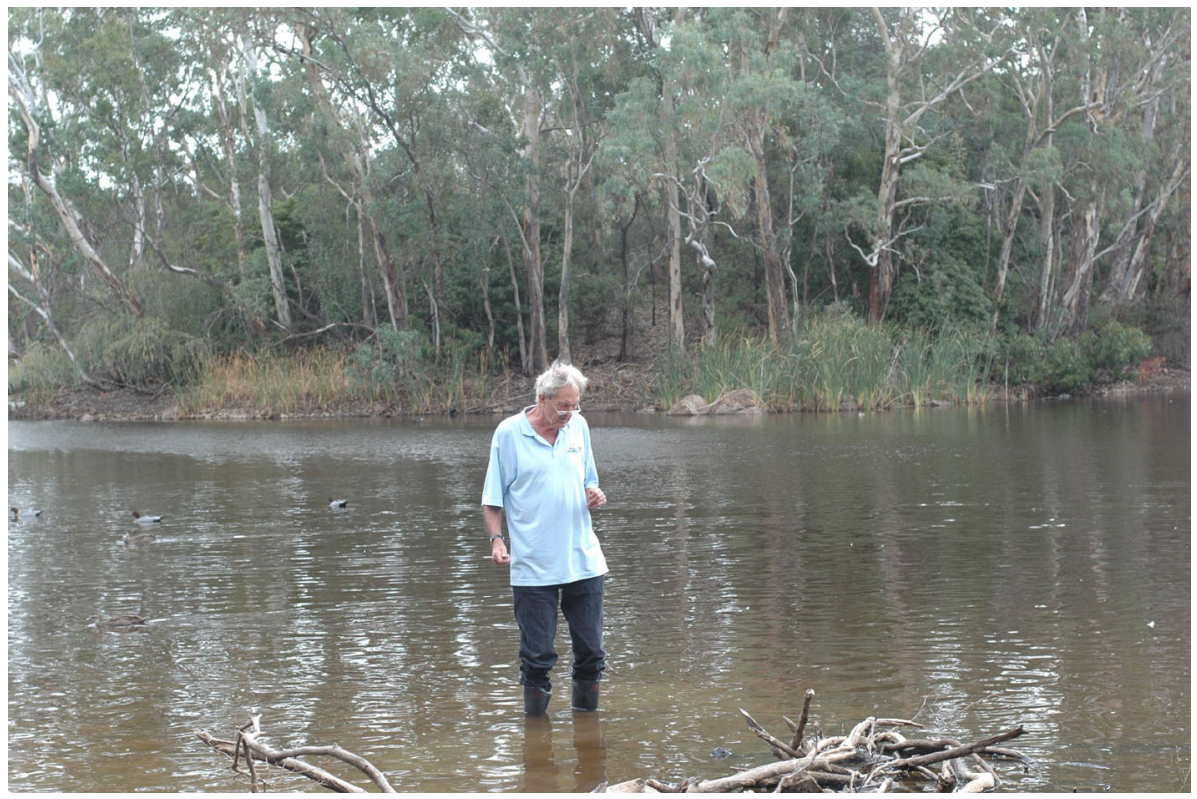

Figure 1. Michael Tyler in the field (wading in an Australian lake). Courtesy of Ella Tyler.

studying the throat musculature of hylid frogs to make comparisons between Australian and New Guinean species and those of the New World. He served as Vice-President (1973-1974) and President (1979-1981) of the Australian Society of Herpetologists, as Vice-President (19831985, 1986-1988) and President (1985-1986) of the Royal Society of South Australia, as President and Chairman of the Board for the Royal Zoological Society of South Australia (19942001), and as President for the Australian Institute of Biology (1995-1997). At the international level, Tyler was director (1991) of the IUCN Declining Amphibian Populations Task Force and its Australian Working Group (chairman, 1991-1997), and a member of the IUCN Species Survival Commission (since 1992).

Beginning in 1983, Tyler held a series of increasingly important positions in the then newly established World Congress of Herpetology. He was a founding member of the International Herpetological Committee and a convener of the symposium "Evolution and Phylogeny of
Frogs" (with Raymond Laurent of Argentina) at the First World Congress of Herpetology (Canterbury, UK, 1989). For the Second World Congress of Herpetology (Adelaide, December 29, 1993 to January 6, 1994), he was head of the local committee that organized and ran the meeting. Later, he served a term as SecretaryGeneral of the world body (1997-2002) during the run up to the Fourth World Congress that was held in Sri Lanka.

We will long remember this gifted, energetic, and friendly man, who was devoted to science and who dearly loved nature in all its various manifestations.

Acknowledgements. We thank Ella Tyler, Mike's widow, for providing some data on the life of Michael Tyler and a list of his publications. The work was completed under the Laboratory Project, Zoological Institute, Russian Academy of Sciences, no. AAAA-A19-119020590095-9 (L.J.B.).

Leo J. Borkin (St. Petersburg, Russia) Kraig Adler (Ithaca, New York, USA) 